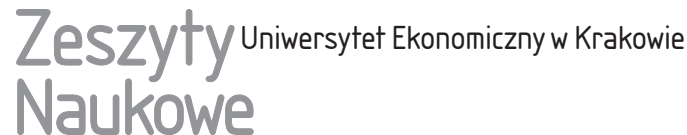

\section{Małgorzata Marchewka}

Studia Doktoranckie Wydziału Zarządzania

Uniwersytet Ekonomiczny w Krakowie

\section{Struktura i dynamika grupowa rad nadzorczych a efektywność przedsiębiorstw*}

\section{Streszczenie}

Rola rad nadzorczych w kształtowaniu wyników przedsiębiorstw jest jednym z kluczowych zagadnień nadzoru korporacyjnego. W artykule opisano badania, których celem było porównanie znaczenia struktury i funkcjonowania rad nadzorczych dla efektywności przedsiębiorstw. Badaniami objęto 291 spółek notowanych na GPW w Warszawie w latach 2010-2013. Dane dotyczące struktury zespołów zebrano na podstawie studiów życiorysów członków rad nadzorczych, natomiast do zgromadzenia informacji na temat dynamiki grupowej wykorzystano opracowany wcześniej kwestionariusz. Z analiz wynika, że ważną cechą struktury zespołów jest zróżnicowanie rodzaju wykształcenia i liczebność zespołów, jednak bezpośredni związek między strukturą a wynikami przedsiębiorstwa jest słaby. Potwierdzono, że efektywność rad nadzorczych zależy od procesów grupowych, w szczególności od spójności, konfliktu poznawczego i norm wysiłku, na które wpływ ma struktura wykształcenia.

Wnioski z badań przyczyniają się do lepszego zrozumienia funkcjonowania rad nadzorczych, a także umożliwiają kształtowanie procesów grupowych sprzyjających efektywności zespołów i efektywności przedsiębiorstw.

Słowa kluczowe: rada nadzorcza, struktura zespołu, efektywność, dynamika grupowa.

* Niniejszy artykuł przygotowano w ramach projektu badawczego. Projekt został sfinansowany ze środków Narodowego Centrum Nauki, przyznanych na podstawie decyzji nr UMO$-2011 / 01 / \mathrm{N} / \mathrm{HS} 4 / 02166$. 


\section{Wprowadzenie}

Zainteresowanie zespołami naczelnego kierownictwa w roli podstawowego decydenta w przedsiębiorstwie stało się bodźcem do badania cech funkcjonowania zarządów i rad nadzorczych jako czynników determinujących efektywność przedsiębiorstw. Dodatkowo przyjęcie założenia wynikającego z upper echelons theory [Hambrick i Mason 1984], dotyczącego częściowej zależności między naczelnymi organami kierownictwa a wynikami przedsiębiorstw, zaowocowało wieloma badaniami w tym obszarze. Identyfikowanie czynników determinujących efektywność przedsiębiorstwa związanych ze strukturą naczelnych organów kierownictwa stało się jednym z kluczowych zagadnień Corporate Governance. Równocześnie wyniki zagranicznych badań nie pozwalają na określenie jednoznacznych zależności, w Polsce zaś temat ten został podjęty przez niewielu badaczy [Peszko 2006, Bohdanowicz 2010].

Celem artykułu jest przedstawienie wyników empirycznego ujęcia problemu zależności między strukturą i dynamiką grupową rad nadzorczych a efektywnością przedsiębiorstw. Zgromadzono dane dotyczące struktury rad nadzorczych 291 spółek notowanych w latach 2010-2013 na rynku podstawowym Giełdy Papierów Wartościowych w Warszawie oraz dane na temat dynamiki grupowej 46 rad nadzorczych wybranych z powyższej grupy spółek. W wyniku analizy wyłoniono elementy struktury i dynamiki grupowej rad nadzorczych, które są istotne w kontekście wyników przedsiębiorstwa.

\section{Struktura rady nadzorczej}

Badania naczelnych organów kierownictwa są związane głównie z efektywnością przedsiębiorstwa. Rady nadzorcze są coraz częściej poddawane analizie jako grupy podejmujące decyzje. We współczesnych badaniach dominuje ujęcie statyczne, w którym najistotniejsze są cechy zespołu i ich wpływ na wyniki przedsiębiorstwa. Badane cechy to między innymi wielkość i skład grupy, czas pełnienia funkcji, wiek członków oraz ich doświadczenie i kompetencje.

Demograficzny model efektywności przedsiębiorstwa przedstawiony na rys. 1 łączy wyniki spółki ze strukturą społeczną zespołów naczelnego kierownictwa (np. wiek, płeć, wykształcenie, doświadczenie, pochodzenie decydujące o heterogeniczności zespołu).

Z teoretycznych rozważań wynika, że przewagą dużych zespołów jest różnorodność umiejętności i doświadczeń jego członków. W przypadku rad dyrektorów, w jednopoziomowym systemie władania korporacyjnego, często wymieniane korzyści wynikające z dużej liczebności członków zespołu to możliwość nawią- 
zania wielu relacji z otoczeniem, lepsze zabezpieczenie zasobów, a także wyższa jakość i wszechstronność opinii wydawanych przez radę. Równocześnie większa różnorodność zespołu jest szansą na wielopłaszczyznowe spojrzenie na problemy organizacji i większy potencjał innowacyjny [Wiersema i Bantel 1992].

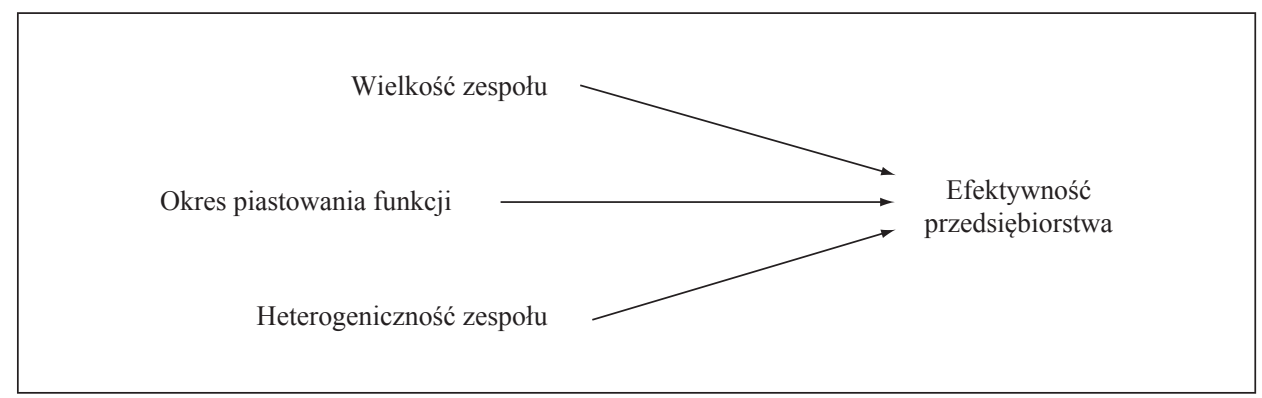

Rys. 1. Demograficzny model efektywności przedsiębiorstwa Źródło: [Smith i in. 1994, s. 417].

Jednakże zbyt duże rady mogą mieć trudność w sprawnym realizowaniu przypisanych im funkcji - mogą doświadczać trudności komunikacyjnych, czego rezultatem bywa niewłaściwe dzielenie się informacjami i możliwa dominacja przewodniczącego rady [Elsayed 2009, s. 418] albo efekt rozproszenia odpowiedzialności, tzw. próżniactwo społeczne (social loafing) [Castro i in. 2009]. Kłopotem może być także utrata spójności przez grupę.

Jak wynika z dotychczasowych studiów, podejście statyczne nie pozwala na stwierdzenie jednoznacznych relacji między właściwościami rad nadzorczych a ich efektywnością. Badania nad wielkością rady nadzorczej, jej składem i efektywnością organizacji przeprowadzone w latach 1998 - 2007 przez A. Bermiga i B. Fricka [2010] z udziałem 294 niemieckich przedsiębiorstw doprowadziły badaczy do nieoczekiwanych wniosków. Przyznają, że uzyskane rezultaty nie pozwoliły na sformułowanie spodziewanego spójnego efektu ani na temat wielkości rady, ani jej składu i ich związku z wynikami gospodarczymi. W innych badaniach [Van der Walt i in. 2006] próbowano ustalić zależność między efektywnością zespołu kierowniczego a stopniem jego zróżnicowania pod względem wieku, płci, pochodzenia etnicznego i umiejętności. Jednak badania nie potwierdziły hipotezy, że większa różnorodność zapewnia wyższą skuteczność. Trudno ustalić jednoznaczną relację między cechami grupy a efektywnością przedsiębiorstwa. Sugeruje to, że wpływ cech rady nadzorczej na wyniki ekonomiczne nie jest prosty ani bezpośredni [Forbes i Milliken 1999, s. 490]. 


\section{Dynamika grupowa rady nadzorczej}

Zdaniem D.A. Nadlera [2004], kluczem do zrozumienia ładu korporacyjnego jest dynamika interakcji naczelnych organów kierowniczych oraz ich kompetencje, przynależność i konstruktywne zaangażowanie członków. Alternatywą dla statycznego opisu rad nadzorczych jest podejście dynamiczne, które poza cechami strukturalnymi uwzględnia również procesy grupowe. Niektórzy badacze twierdzą, że dynamika zespołów kierowniczych jest najważniejszym czynnikiem determinującym ich efektywność, która z kolei jest podstawą do osiągania celów przedsiębiorstwa [Leblanc i Gillies 2003].

Każdą grupę można scharakteryzować, opisując jej cechy statyczne, do których należą między innymi liczba członków, ich cechy demograficzne, struktura grupy (tj. sieć ról i hierarchia statusów), wiedza i umiejętności posiadane przez poszczególnych członków. Taki opis często jest niewystarczający, ponieważ nie ujmuje bogactwa, które niosą ze sobą relacje interpersonalne. Konieczne jest więc uwzględnienie właściwości funkcjonowania grupy. To założenie stanowi podstawę koncepcji dynamiki grupowej, w której elementami analizy są procesy grupowe. Wśród nich za podstawowe należy uznać proces stawania się członkiem grupy, spójność grupy czy nabywanie i rozwój norm grupowych [Brown 2006]. Spojrzenie na naczelne organy kierownictwa przedsiębiorstwa przez pryzmat procesów grupowych jako na zespoły podejmujące decyzje otwiera nowe możliwości badania zarządów i rad nadzorczych. Jednym z prekursorów takiego podejścia był Kurt Lewin, który badał dynamikę i procesy podejmowania decyzji w zespołach menedżerskich [Papanek 1973].

Dodatkowo należy uwzględnić specyfikę funkcjonowania rad nadzorczych i rad dyrektorów, które od innych zespołów różnią się m.in. przynależnością członków zespołu do przedsiębiorstwa, częstotliwością spotkań oraz dostępem do wewnętrznych informacji spółek [Levrau i Van den Berhe 2007]. Autorami szczegółowej analizy dynamiki grupowej zespołów naczelnego kierownictwa są D.P. Forbes i F.J. Milliken [1999]. Wyróżniają oni trzy procesy, które uważają za najistotniejsze elementy dynamiki zespołów najwyższego kierownictwa. Są to normy wysiłku, konflikt poznawczy i wykorzystanie posiadanej wiedzy i umiejętności (rys. 2).

Normy wysiłku odnoszą się do podzielanego w grupie przekonania na temat poziomu wysiłku, który jest wymagany od każdego z członków grupy. Wysiłek wynika z motywacji i intensywności indywidualnego zaangażowania w zadania, przejawiającego się między innymi zapoznaniem się z sytuacją przedsiębiorstwa i jej zrozumieniem. Oprócz czasu poświęconego na przygotowanie się do spotkań, normy wysiłku dotyczą dokładności analizy dostępnych informacji i zaangażowania w dyskusje toczące się podczas posiedzeń. Podczas gdy normy wysiłku 
dotyczą oczekiwań co do intensywności indywidualnych zachowań, konflikt poznawczy odnosi się do braku zgodności pomiędzy członkami rady czy zarządu w kwestiach związanych z realizowanymi zadaniami.

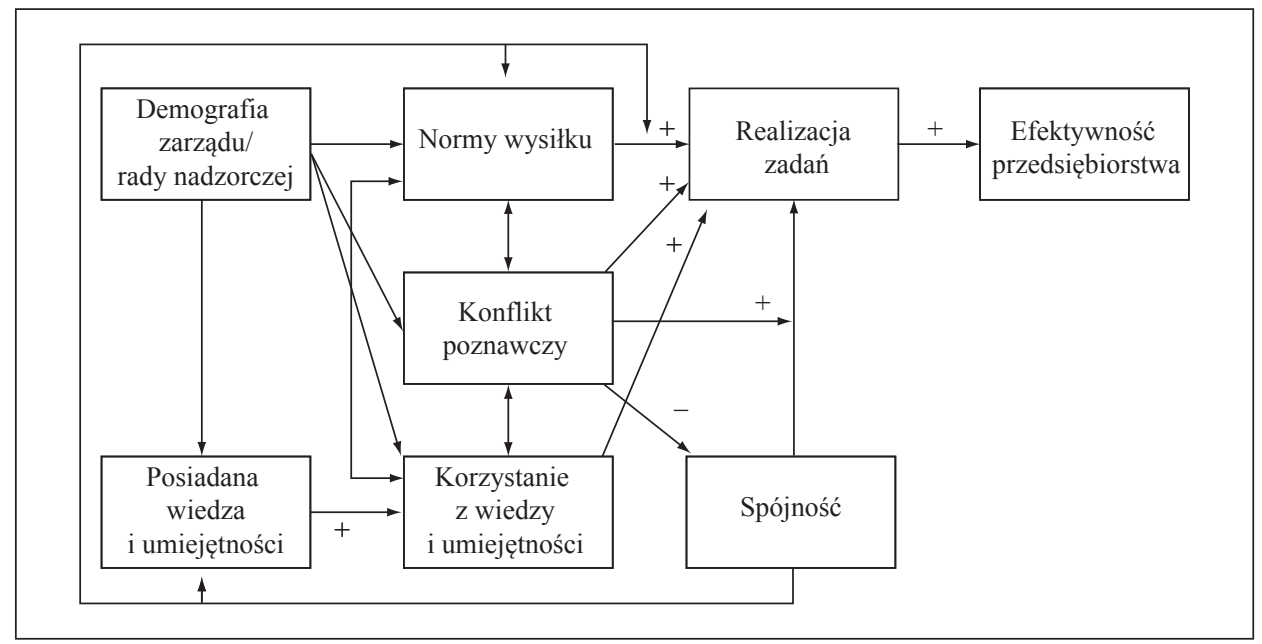

Rys. 2. Model dynamiki grupowej zespołów naczelnego kierownictwa Źródło: [Forbes i Milliken 1999, s. 498].

Konflikt poznawczy dotyczy stopnia, w jakim w grupie ujawniane są różne, czasem przeciwstawne, opinie związane z rozwiązywanymi problemami. $\mathrm{Na}$ proces ten składają się interakcje, których celem jest dopytywanie, uzasadnianie czy krytyka. W efekcie prowadzi on do poszerzenia liczby rozpatrywanych propozycji i dokładniejszej oceny różnych opcji. Jego konsekwencją może być także wzrost negaty wnych emocji, które zmniejszają wzajemną atrakcyjność interpersonalną członków grupy.

Kolejnym czynnikiem składającym się na model Forbesa i Milliken jest spójność grupy, która decyduje o wzajemnej atrakcyjności członków grupy. Zależność między spójnością a efektywnością grupy ma charakter krzywoliniowy. Oznacza to, że do pewnego momentu wzrost spójności grupy wiąże się z wyższym poziomem wykonania, natomiast po przekroczeniu tego punktu, wzrost spójności obniża poziom wykonania. Zbyt wysoki poziom spójności może skutkować między innymi syndromem myślenia grupowego czy redukowaniem konfliktu poznawczego. Najkorzystniejszy jest poziom umiarkowany, który wspiera dyskutowanie i analizowanie różnych scenariuszy.

W przedstawionym modelu brak bezpośredniego wpływu strukturalnych cech grupy na jej efektywność. Charakterystyka zespołu wpływa na procesy grupowe, które pozwalają wnioskować o skuteczności w realizacji zadań. Warto też 
zaznaczyć, że poszczególne procesy nie toczą się niezależnie, lecz są wzajemnie powiązane.

Na koniec należy podkreślić, że badania nad dynamiką grupy obejmują także jej strukturę. Cechy statyczne zespołu nie są pominięte, ale równocześnie nie poszukuje się ich bezpośrednich związków z wynikami ekonomicznymi przedsiębiorstwa. Badacze poszukują zależności między cechami grupy czy kontekstu a przebiegiem procesów grupowych. Na przykład C.S. Tuggle i in. [2010] przeprowadzili analizę zależności między składem zespołu kierowniczego a procesem dyskutowania i uzgadniania. Naczelne organy kierownictwa między innymi cechują: okres pełnienia funkcji, różnorodność funkcjonalnych obszarów specjalizacji i różnorodność branżowa. Wyniki ich badań wskazują, że poziom różnorodności może zwiększyć liczbę pytań, poprawić jakość dyskusji i prowadzić do uważniejszej analizy przedstawianych pomysłów. Dynamika grupowa okazuje się skutecznym narzędziem przewidywania efektywności naczelnych organów kierownictwa i przedsiębiorstwa.

\section{Podstawowe mierniki efektywności przedsiębiorstwa}

W tradycyjnym ujęciu finansowym efektywność przedsiębiorstwa jest rozumiana jako maksymalizacja efektów finansowych i mierzona jest za pomocą wskaźników związanych z kategoriami finansowymi [Sierpińska i Jachna 2006]. Jedną z metod nawiązującą częściowo do oceny efektywności jest koncepcja oceny produktywności, wyrażającej zdolność do generowania efektów przez poszczególne typy działalności przedsiębiorstwa [Stabryła 2006, s. 346-356].

Zgodnie z nowym podejściem, propagowanym przez R.V. Aguilerę, K.A. Desendera i de L.R.K. Castro [2012], wyniki przedsiębiorstwa zależą od efektywności „wiązki” mechanizmów nadzoru, a nie od efektywności poszczególnych mechanizmów. Oznacza to, że oceniając efektywność nie wystarczy odnieść się do rezultatów przedsiębiorstwa, ale należy przyjąć szerszą perspektywę interesariuszy. Efektywność przedsiębiorstwa jest więc interpretowana w kategoriach efektów dla interesariuszy i spełniania ich wymagań.

Analiza badań dotyczących zależności efektywności przedsiębiorstwa od struktury zarządów, rad nadzorczych i rad dyrektorów prowadzi do wniosku, że najczęściej uwzględnia się jej tradycyjne - finansowe - rozumienie, co skutkuje stosowaniem mierników głównie księgowych i rynkowych [Carpenter i Fredrickson 2001, Carpenter 2002, Van Ees, Postma i Sterken 2003, Peszko 2006, Van der Walt i in. 2006, McIntyre, Murphy i Mitchell 2007, Bermig i Frick 2010, Bohdanowicz 2010, Hsu 2010, Van-Ness, Miesing i Kang 2010]. Na podstawie przeglądu autorstwa K. Elsayeda [2009, s. 420-422] obejmującego dwadzieścia innych niż wymieniono 
badań nad zależnościami między wielkością organów naczelnego kierownictwa a efektywnością przedsiębiorstwa, których wyniki zostały opublikowane w latach 1996-2009, można stwierdzić, że najczęściej używane wskaźniki to ROA, ROE, ROS, Q Tobina, wskaźnik C/WK (wartość rynkowa/wartość księgowa) oraz wartość akcji spółki. Znacznie rzadziej wykorzystywane są mierniki związane z szerzej rozumianą efektywnością, odnoszące się na przykład do transparentności spółek [Wan i Ong 2005] czy wartości dla interesariuszy.

\section{Struktura i dynamika grupowa rad nadzorczych wybranych spółek notowanych na Giełdzie Papierów Wartościowych w Warszawie a ich efektywność}

\subsection{Hipotezy badawcze}

Głównym celem badania było porównanienie znaczenia struktury rad nadzorczych kierownictwa i ich dynamiki grupowej dla wyników przedsiębiorstwa. W kolejnej części artykułu opisano weryfikowane hipotezy badawcze, próbę badawczą, metody badania i osiągnięte wyniki.

$\mathrm{Na}$ podstawie przedstawionej analizy literatury w badaniach własnych postawiono następujące hipotezy badawcze:

- związki pomiędzy efektywnością przedsiębiorstw a dynamiką grupową rad nadzorczych są silniejsze niż związki między efektywnością przedsiębiorstw a strukturą tych zespołów,

- między strukturą rad nadzorczych a efektywnością przedsiębiorstw nie istnieje bezpośrednia zależność,

- cechy strukturalne naczelnych organów kierownictwa wpływają na procesy grupowe determinujące efektywność zespołów zarządzających i efektywność przedsiębiorstw.

\subsection{Próba badawcza}

Próbę badawczą stanowiło 291 spółek notowanych w latach 2010-2013 na rynku podstawowym Giełdy Papierów Wartościowych w Warszawie. Na podstawie studiów życiorysów członków rad nadzorczych zgromadzono dane dotyczące struktury zespołów - liczebności, rotacji, rodzaju i poziomu wykształcenia, doświadczenia, a także zróżnicowania pod względem płci i pochodzenia. Zgromadzono także dane na temat wyników finansowych przedsiębiorstw. Z kolei podstawą drugiej części badania były dane kwestionariuszowe zebrane internetowo lub podczas wywiadów od 46 przedstawicieli różnych rad nadzorczych spółek z opisanej wyżej grupy badawczej. 


\subsection{Zmienne badawcze i metody pomiaru}

Struktura rad nadzorczych

Badane cechy struktury to:

- liczba członków rady nadzorczej,

- rotacja członków rady nadzorczej (wyrażona stosunkiem liczby osób należących do rady nadzorczej w badanym okresie do liczby stanowisk w radzie nadzorczej),

- poziom edukacji członków rady nadzorczej (wyrażony zdobytymi stopniami i tytułami naukowymi),

- dziedzina wykształcenia członków rady nadzorczej (wyróżniono cztery obszary specjalizacji: wykształcenie techniczne, ekonomiczne, prawnicze i inne),

- płeć członków rady nadzorczej,

- obywatelstwo członków rady nadzorczej.

Uwzględniono również poziom zróżnicowania rady nadzorczej pod względem dziedziny i poziomu wykształcenia członków rady oraz ich płci i obywatelstwa. Podobnie jak w badaniach M.A. Carpentera [2002, s. 8] oraz R.K. Van-Nessa i in. [2010], do określenia stopnia zróżnicowania wykorzystano indeks Blaua (IB) wyrażony wzorem:

$$
I B=1-\Sigma p_{i}^{2},
$$

gdzie $p_{i}$ to procentowy udział osób reprezentujących daną cechę. Im wartość wskaźnika jest wyższa, tym różnorodność związana z daną kategorią jest większa.

Dane dotyczące struktury zespołów zostały zgromadzone na podstawie studiów życiorysów ich członków. Informacje były publikowane w raportach bieżących spółek w momencie powołania członków do pracy w radach nadzorczych. W ramach badań przestudiowano około 3000 życiorysów.

\section{Dynamika grupowa rad nadzorczych}

Dynamika grupowa rad nadzorczych była analizowana na podstawie danych kwestionariuszowych dotyczących pięciu obszarów: spójności, norm wysiłku, konfliktu poznawczego, konfliktu afektywnego, przywództwa. Ankiety zostały wypełnione (internetowo lub podczas wywiadów) przez 46 członków różnych rad nadzorczych spośród spółek notowanych w latach 2010-2013 na rynku podstawowym Giełdy Papierów Wartościowych w Warszawie. Z uwagi na trudny dostęp do osób zasiadających w radach nadzorczych dobór próby nie był losowy, co należy uwzględnić, formując wnioski z analiz. 


\section{Efektywność przedsiębiorstw}

Efektywność przedsiębiorstw mierzono za pomocą dwóch wskaźników zmiany rentowności aktywów ( $\triangle \mathrm{ROA})$ i Q Tobina. Wartość wskaźnika Q Tobina obliczano na podstawie następującego uproszczonego wzoru stosowanego między innymi przez L. Bohdanowicza [2010, s. 22]:

$$
\begin{gathered}
\text { przybliżona } \\
\text { wartość } \\
\text { Q Tobina }
\end{gathered}=\frac{\begin{array}{c}
\text { wartość rynkowa } \\
\text { kapitału akcyjnego }
\end{array}+\begin{array}{c}
\text { zobowiązania } \\
\text { krótkoterminowe }
\end{array}+\begin{array}{c}
\text { zobowiązania } \\
\text { długoterminowe }
\end{array}}{\text { księgowa wartość aktywów ogółem }} .
$$

Do analizy wykorzystano dane z rocznych skonsolidowanych raportów finansowych oraz informacje dostępne na stronie internetowej Giełdy Papierów Wartościowych w Warszawie i na stronach internetowych spółek.

\subsection{Analiza wyników badań}

Na pierwszym etapie analizy zastosowano eksploracyjną analizę czynnikową w celu wyodrębnienia czynników istotnych dla struktury i dynamiki grupowej rad nadzorczych, na drugim zaś etapie - ze względu na dużą złożoność relacji pomiędzy zmiennymi w badaniu - wykorzystano modelowanie równań strukturalnych (analizę ścieżek oraz konfirmacyjną analizę czynnikową). Są to metody wykraczające poza poszukiwanie prostych zależności pomiędzy zmiennymi, a specyfika badanego zjawiska wymagała uwzględniania jego złożoności. Wyniki istotne statystycznie (na poziomie $p<0,05$ ) oznaczono gwiazdką.

Na rys. 3 przedstawiono wyniki analiz dotyczących wpływu struktury zespołu naczelnego kierownictwa na efektywność przedsiębiorstwa. Na podstawie eksploracyjnej analizy czynnikowej ustalono, że uwzględniając strukturę zespołu, ważne są dwie grupy zmiennych: zmienne dotyczące struktury dziedzin wykształcenia (udział osób z wykształceniem ekonomicznym, udział osób z wykształceniem prawniczym, zróżnicowanie dziedzin wykształcenia) oraz zmienne dotyczące struktury poziomu wykształcenia (udział osób ze stopniem naukowym doktora i tytułem profesora, zróżnicowanie poziomów wykształcenia), a także pojedyncze zmienne, takie jak: liczebność zespołu, rotacja oraz zróżnicowanie pod względem płci i pochodzenia.

Z kolei z analizy ścieżek wynika, że dla efektywności przedsiębiorstwa ważne jest zróżnicowanie specjalności i wykształcenia członków rad nadzorczych, przy czym korzystna jest sytuacja, gdy liczba ekonomistów przeważa liczbę prawników. Mniej istotne jest zróżnicowanie poziomu wykształcenia, natomiast na uwagę zasługuje liczebność rad nadzorczych. 


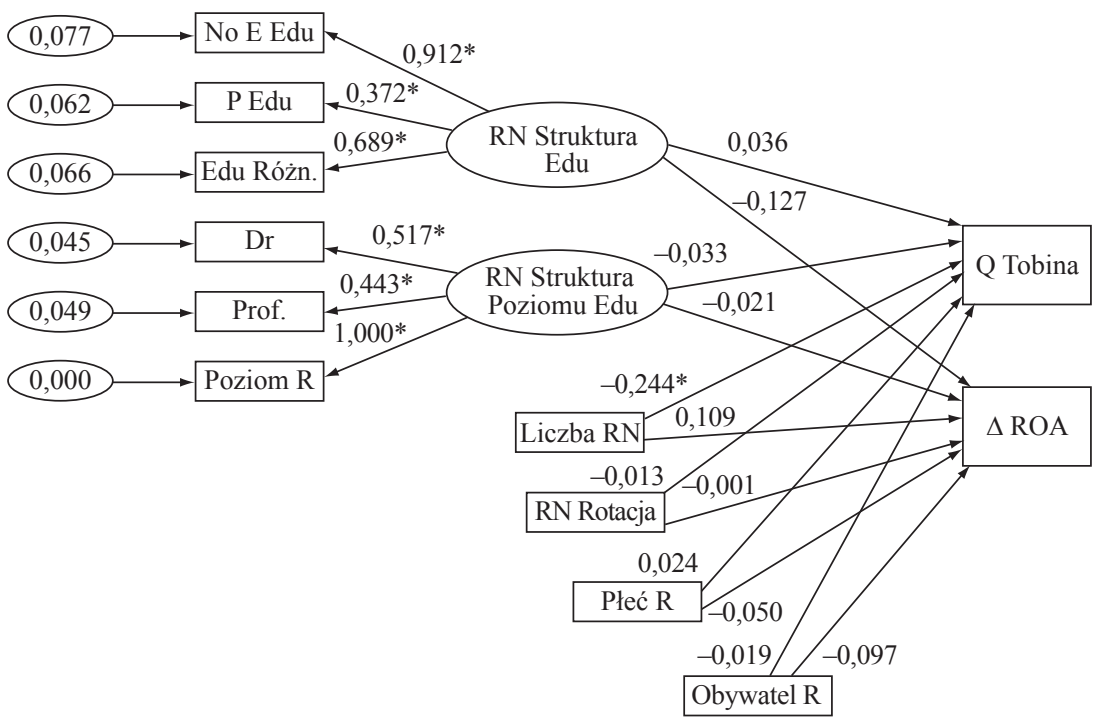

Oznaczenia: RN Struktura Edu - struktura wykształcenia członków rady nadzorczej, No E Edu brak wykształcenia ekonomicznego, P Edu - wykształcenie prawnicze, Edu Różn. - różnorodność wykształcenia członków rady nadzorczej (indeks Blaua), RN Struktura Poziomu Edu - struktura poziomu wykształcenia członków rady nadzorczej, Poziom $\mathrm{R}$ - różnorodność poziomu wykształcenia członków rady nadzorczej (indeks Blaua), Liczba RN - liczba członków rady nadzorczej, RN Rotacja - rotacja członków rady nadzorczej, Płeć R - różnorodność płci (indeks Blaua), Obywatel R - różnorodność obywatelstwa (indeks Blaua).

Rys. 3. Wpływ struktury rady nadzorczej na wyniki przedsiębiorstwa Źródło: opracowanie własne.

Na podstawie analiz można zaobserwować tendencję do osiągania przez mniejsze zespoły lepszych wyników mierzonych za pomocą wskaźnika Q Tobina. Równocześnie wszelkie zidentyfikowane zależności między cechami strukturalnymi rad nadzorczych a wynikami przedsiębiorstwa są słabe, co wskazuje słuszność przypuszczenia, że związek ten nie jest bezpośredni. Wskaźniki dobroci dopasowania skonstruowanego modelu są satysfakcjonujące (np. RMSEA SteigeraLinda wynosi 0,099; wskaźnik Gamma populacji -0,927, a GFI Joreskoga 0,902).

Kolejnym obszarem analizy była dynamika grupowa rad nadzorczych (rys. 4). Podstawą tej części badania były dane kwestionariuszowe zebrane internetowo lub podczas wywiadów od 46 przedstawicieli różnych rad nadzorczych spółek z opisanej wcześniej grupy badawczej. Na podstawie eksploracyjnej analizy czynnikowej ustalono, że największe znaczenie dla dynamiki grupowej mają spójność, konflikt poznawczy i normy wysiłku. 


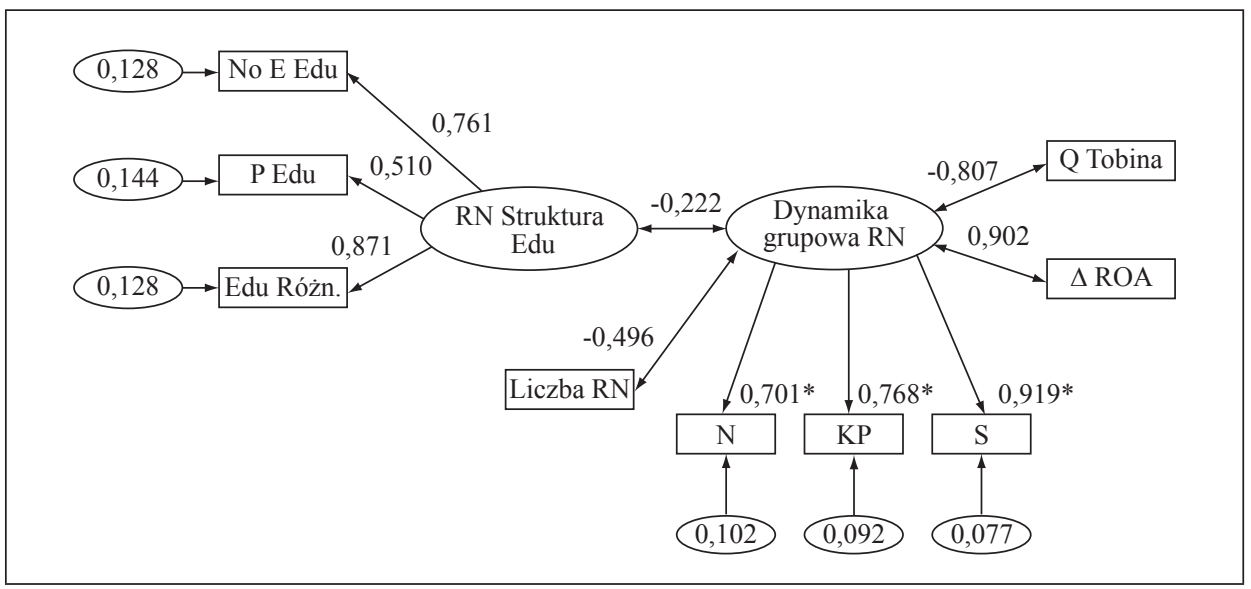

Oznaczenia: S - spójność, KP - konflikt poznawczy, N - normy wysiłku, RN Struktura Edu struktura wykształcenia członków rady nadzorczej, No E Edu - brak wykształcenia ekonomicznego, P Edu - wykształcenie prawnicze, Edu Różn. - różnorodność wykształcenia członków rady nadzorczej (indeks Blaua), Liczba RN - liczba członków rady nadzorczej.

Rys. 4. Związki pomiędzy dynamiką grupową rad nadzorczych a wynikami przedsiębiorstw

Źródło: opracowanie własne.

Dalsze badania z wykorzystaniem analizy ścieżek potwierdziły, że efektywność rad nadzorczych zależy od dynamiki grupowej (współczynnik regresji wyniósł $56 \%$ i jest istotny statystycznie na poziomie ufności $p<0,05)$, a w szczególności od spójności, konfliktu poznawczego i norm grupowych.

Chociaż z uwagi na ograniczoną liczbę danych dotyczących dynamiki grupowej niemożliwe jest wnioskowanie na temat ogólnych związków między funkcjonowaniem rady nadzorczej a efektywnością przedsiębiorstwa, jednak za pomocą konfirmacyjnej analizy czynnikowej zidentyfikowano zależność między dynamiką grupową a wynikami spółek wyrażoną wskaźnikiem Q Tobina i $\triangle$ ROA. Równocześnie stwierdzono związek dynamiki grupowej ze strukturą zespołu, szczególnie ze strukturą wykształcenia członków rad nadzorczych. Wskaźniki dobroci dopasowania skonstruowanego modelu są satysfakcjonujące (np. RMSEA Steigera-Linda wynosi 0,000; wskaźnik Gamma populacji-1,000, a GFI Joreskoga 0,832). Brak odpowiedniej liczby danych uniemożliwił statystyczne zweryfikowanie hipotezy na temat istotoności związków pomiędzy wynikami przedsiębiorstwa a dynamiką grupową rad nadzorczych, jednak stwierdzone prawidłowości wskazują, że rola procesów grupowych nie może być pominięta. 


\section{Wnioski i podsumowanie}

Przeprowadzone badanie przyczyniło się do pogłębienia wiedzy dotyczącej zależności pomiędzy strukturą i funkcjonowaniem zespołów naczelnego kierownictwa a wynikami przedsiębiorstw, stanowiąc wsparcie dla rozważań teoretycznych podejmowanych w Polsce i za granicą. $Z$ analiz wynika, że bezpośrednia zależność istniejąca między strukturą rad nadzorczych a efektywnością przedsiębiorstw jest bardzo słaba, podczas gdy dynamika grupowa ma większe znaczenie dla wyników przedsiębiorstwa. Równocześnie procesy grupowe zależą od cech struktury zespołu, głównie od struktury wykształcenia.

Ponieważ do tej pory przeprowadzono niewiele badań dotyczących procesów grupowych charakterystycznych dla zespołów naczelnego kierownictwa, wartość próby polega na dostarczeniu obserwacji związanych ze strukturą i funkcjonowaniem rad nadzorczych i zarządów oraz na wyeksponowaniu problemów, które należy rozwiązać, prowadząc kolejne badania w tym obszarze. Główne ograniczenia wiążą się z trudnym dostępem do członków rad nadzorczych, którzy chcieliby wyrazić zgodę na opisanie funkcjonowania ich zespołów. Jednocześnie wypracowane wnioski skłaniają do pogłębiania badań nad wybranymi cechami struktury zespołów naczelnego kierownictwa (wykształcenia członków zespołów i rotacji) oraz ich dynamiki grupowej (spójność, konflikt poznawczy i normy wysiłku).

\section{Literatura}

Aguilera R.V., Desender K.A., Castro L.R.K. [2012], A Bundle Perspective to Comparative Corporate Governance [w:] The SAGE Handbook of Corporate Governance, red. T. Clarke, D. Branson, Sage Publications, New York.

Bermig A., Frick B. [2010], Board Size, Board Composition, and Firm Performance: Empirical Evidence from Germany, Working Papers, http://ssrn.com/abstract=1623103 (dostęp: 15.01.2011).

Bohdanowicz L. [2010], Wpływ liczebności rad nadzorczych i zarzadów spółek publicznych na wyniki spótek, „,Master of Business Administration”, vol. 18, nr 3.

Brown R. [2006], Procesy grupowe. Dynamika wewnatrzgrupowa i międzygrupowa, Gdańskie Wydawnictwo Psychologiczne, Gdańsk.

Carpenter M.A. [2002], The Implications of Strategy and Social Context for the Relationship between Top Management Team Heterogeneity and Firm Performance, ,Strategic Management Journal", vol. 23(3), http://dx.doi.org/10.1002/smj.226.

Carpenter M.A., Fredrickson J.W. [2001], Top Management Teams, Global Strategic Posture, and the Moderating Role of Uncertainty, „Academy of Management Journal”, vol. 44(3), http://dx.doi.org/10.2307/3069368. 
Castro C.B., De La Concha M.D., Gravel J.V., Periñan M.M.V. [2009], Does the Team Leverage the Board's Decisions?, „Corporate Governance: An International Review”, vol. 17(6), http://dx.doi.org/10.1111/j.1467-8683.2009.00772.x.

Elsayed K. [2009], Board Size and Corporate Performance: the Missing Role of Board Leadership Structure, ,Journal of Management \& Governance”, nr 15(3), http://dx.doi. org/10.1007/s10997-009-9110-0.

Forbes D.P., Milliken F.J. [1999], Cognition and Corporate Governance: Understanding Boards of Directors as Strategic Decision-making Groups, ,The Academy of Management Review", vol. 24(3), http://dx.doi.org/10.2307/259138.

Hambrick D., Mason P.A. [1984], Upper Echelons: The Organization as a Reflection of Its Top Managers, „The Academy of Management Review”, vol. 9(2), http://dx.doi. org/10.2307/258434.

Hsu H. [2010], The Relationship between Board Characteristics and Financial Performance: An Empirical Study of United States Initial Public Offerings, ,International Journal of Management", vol. 27(2).

Leblanc R., Gillies J. [2003], The Coming Revolution in Corporate Governance, „Ivey Business Journal", vol. 68(1).

Levrau A., Van den Berghe L.A.A. [2007], Corporate Governance and Board Effectiveness: Beyond Formalism, „ICFAI Journal of Corporate Governance”, vol. 6(4).

McIntyre M.L., Murphy S.A., Mitchell P. [2007], The Top Team: Examining Board Composition and Firm Performance, ,Corporate Governance”, vol. 7(5).

Nadler D.A. [2004], Building Better Boards, „Harvard Business Review”, vol. 82(5).

Papanek M.L. [1973], Kurt Lewin and his Contributions to Modern Management Theory, „Academy of Management Proceedings”, nr 1, http://dx.doi.org/10.5465/ ambpp.1973.4981410.

Peszko A. [2006], Rada nadzorcza w procesie zarzadzania przedsiębiorstwem, Difin, Warszawa.

Sierpińska M., Jachna T. [2006], Ocena przedsiębiorstwa według standardów światowych, PWN, Warszawa.

Smith K.G., Smith K.A., Olian J.D., Sims Jr. H.P., O’Bannon D.P., Scully J.A. [1994], Top Management Team Demography and Process: The Role of Social Integration and Communication, „Administrative Science Quarterly”, vol. 39(3), http://dx.doi. org/10.2307/2393297.

Stabryła A. [2006], Zarzadzanie projektami ekonomicznymi i organizacyjnymi, Wydawnictwo Naukowe PWN, Warszawa.

Tuggle C.S., Schnatterly K., Johnson R.A. [2010], Attention Patterns in the Boardroom: How Board Composition and Processes Affect Discussion of Entrepreneurial Issues, ,Academy of Management Journal”, vol. 53(3), http://dx.doi.org/10.5465/ amj.2010.51468687.

Van der Walt N., Ingley C., Shergill G.S., Townsend A. [2006], Board Configuration: Are Diverse Boards Better Boards?, „Corporate Governance: The International Journal of Business in Society", vol. 6, nr 2, http://dx.doi.org/10.1108/14720700610655141.

Van Ees H., Postma T.J.B.M., Sterken E. [2003], Board Characteristics and Corporate Performance in the Netherlands, „Eastern Economic Journal”, vol. 29(1).

Van Ness R.K., Miesing P., Kang J. [2010], Board of Director Composition and Financial Performance in Sarbanes-Oxley World, ,Academy of Business and Economics Journal", vol. 10(5). 
Wan D., Ong C.H. [2005], Board Structure, Process and Performance: Evidence from Public-listed Companies in Singapore, „Corporate Governance: An International Review", vol. 13(2), http://dx.doi.org/10.1111/j.1467-8683.2005.00422.x.

Wiersema M.F., Bantel K.A. [1992], Top Management Team Demography and Corporate Strategic Change, „Academy of Management Journal”, nr 35(1), http://dx.doi. org/10.2307/256474.

\section{Supervisory Board Structure and Group Dynamics as Determinants of Company Performance}

(Abstract)

The role of supervisory boards (SB) in shaping company performance is one of the key issues of corporate governance. The article describes a study comparing the importance of the structure and functioning of SB for company performance. The study examined 291 companies listed on the Warsaw Stock Exchange (from 2010 to 2013). The data on the structure of SB was based on the study of board member CVs, while in the analysis of group dynamics data from the survey was used. The analysis showed that the diversity of educational degrees and the size of the board are important features of the structure, but the direct relationship between the structure and company performance is weak. It was confirmed that the effectiveness of SB depends on group processes, such as cohesion, cognitive conflict and effort norms, which are affected by the structure of education.

The results provide insight into the issue and enable the development of group processes conducive to board effectiveness and company performance.

Keywords: supervisory board, team structure, effectiveness, group dynamics. 